\title{
To compare the efficacy of Drotaverine hydrochloride and Valethamate bromide in shortening of the first stage of labour
}

\author{
Sangeeta Raman Jogi*
}

Department of Obstetrics and Gynaecology, Chhattisgarh Institute of Medical Sciences, Bilaspur, Chhattisgarh, India

Received: 22 July 2015

Accepted: 24 July 2015

\section{*Correspondence:}

Dr. Sangeeta Raman Jogi,

E-mail: raman.jogi@yahoo.com

Copyright: () the author(s), publisher and licensee Medip Academy. This is an open-access article distributed under the terms of the Creative Commons Attribution Non-Commercial License, which permits unrestricted non-commercial use, distribution, and reproduction in any medium, provided the original work is properly cited.

\begin{abstract}
Background: To compare the efficacy of Drotaverine Hydrochloride and Valethamate Bromide in shortening of the first stage of Labor. Drotaverine is more effective in regards of shorten the 1st stage of labor, rate of cervical dilatation with less side effects in compare to Valethamate Bromide.

Methods: Two Hundred demographically similes woman with full term pregnancy in active labour were included in the study and divided into two groups viz.

First Group: 100 women were given injection Drotaverine Hydrochloride (Drotin) $40 \mathrm{mg}$ intramuscularly at 3-4 cm dilation at two hour interval.

Second Group: 100 women were given injection Valethamate Bromide Intramuscularly at 3-4 cm dilation at one hour interval.

Maximum three injections were given in both the groups. Comparative analysis was carried out as regards to duration of various stages of labor, rate of cervical dilatation, mode of delivery, side effects and feto-maternal outcome.

Results: In Group-I Average duration of active phase of first stage of labor was 149.78 minutes.

In Primigravida it was 170.22 minutes and 129.35 minutes in Multigravida.

In Group II Average duration of active phase of first stage of labor was 294.62 minutes.

In Primigravida it was 321.71 minutes and 267.54 minutes in Multigravida.

Average rate of cervical dilatation in Group-I was $2.81 \mathrm{~cm} /$ hour. In Primigravida it was $2.50 \mathrm{~cm} / \mathrm{hour}$ while in Multi gravid it was $3.33 \mathrm{~cm} /$ hour.

In Group-II average rate was $1.42 \mathrm{~cm} /$ hour, in Primigravida it was $1.30 \mathrm{~cm} /$ hour and in Multigravida1.57 cm/hour.

Conclusions: Drotaverine significantly shorten the duration of first stage of labor and found to be safe with no adverse effect on the mother and fetus.
\end{abstract}

Keywords: Drotaverine Hydrochloride, Valethamate Bromide, Cervical dilatation, Labour

\section{INTRODUCTION}

Labour is a multifactorial process which involves myometrium contraction, cervical ripening and dilatation and expulsion of the fetes and the placenta. ${ }^{1}$ In the process of labour, polarity of uterus is maintained by active contraction of upper uterine segment. The driving forces of uterine contraction act upon the cervix which leads to cervical dilatation. It has been observed that the most common cause of the prolonged first stage of labour is cervical spasm which may be due to inflammation, injury or fibrosis of cervix leading to cervical dystocia. ${ }^{2}$

Various spasmolytic medicines, tranquillizers, prostaglandin have been tried but majority of these were four to have side effects on mother and foetus. 
Drotaverine Hydrochloride: It is a phosphodiasterase 4 enzyme inhibitor a new addition to cervical dilator. It was initially used in Europe for spasmodic condition like renal, ureteric and biliary colic and in dysmenorrhea. ${ }^{3,4}$ Its use for cervical dilatation was first studied by Chinoin in 1963 in Hungary. ${ }^{5}$

Drotaverine is Benzyle Iso Quinoline derivative. It causes smooth muscle relaxation by increasing cellular level of cyclic adenosine monophosphate (CAMP), secondary to inhibition of phosphodiesterase four enzyme. The Pharmacological dose of Drotaverine unable to inhibit labour contraction but relaxes only the smooth muscle tone of lower uterine segment and cervix ${ }^{4}$, that's why the active labour pains are not inhibited, It is safe to mother and foetus with no drug interaction. ${ }^{5}$

Valethamate Bromide (Epidosin): It is an ester of quatery ammonium compound; it is an anticholinergic, antispasmodic, musculotropic and neurotropic agent having peripheral action similar to atropine. It is a potent and rapidly acting drug which helps in cervical dilatation. It has side effect like dryness of mouth, flushing of face, nausea, Vomiting, nervousness, giddiness, hypotension due to its effect in smooth muscle of vessel wall. .,6 $^{5}$

\section{METHODS}

A prospective randomized, controlled clinical trial was conducted in the department of obstetrics and Gynecology at Chhattisgarh Institute of Medical Sciences Bilaspur during the period of December 2013 to December 2014.

Detail history of cases has been taken regarding age, occupation and socio economic status. Their presenting complaints were recorded with special attention to Period of amenorrhea, duration since onset of labour pain, leaking per vaginum and other complain. If any obstetric history was elicited regarding outcome of previous pregnancies, any history of prolong labour, retained placenta, abortion, preterm labor or still birth. Past history regarding any major illness or systemic disease was also taken.

Detail Clinical and physical examination have been performed. Per abdomen examination with special attention for height of the uterus, presentation and frequency of contractions was noted. Foetal well-being was monitored by noting the heart rate, rhythm and regularity of foetal heart sound. By per vaginum examination cervical dilatation, effacement, consistency and station of presenting part were noted. Pelvic examination was performed to exclude any pelvic contraction or cephalopelvic disproportion.

Routine investigations advised including $\mathrm{Hb}$, BT,CT, Blood grouping ,Blood sugar, Sickling, VDRL, HIV, $\mathrm{HbS}-\mathrm{Ag}$ and Urine for routine and microscopic examination,
Following inclusion and exclusion criteria were considered for selection of the uncomplicated patients:

\section{Inclusion criteria:}

1. Primi and Multi gravida.

2. Age between 18-35 years.

3. Intact membrane with Vertex presentation.

4. Regular established uterine contraction at the rate of $2 / 10$ minutes with each contraction lasting for 20 seconds.

5. Cervical dilation $3-4 \mathrm{~cm}$.

6. No evidence of maternal or foetal distress.

\section{Exclusion criteria:}

1. Malpresentation.

2. Twin pregnancy.

3. Cervical surgery in past or history of cervical injury.

4. Induced Labor.

5. Maternal Systolic pressure below $100 \mathrm{mmHg}$ or above $150 \mathrm{mmHg}$.

6. Known hypersensitivity to Drotaverine or Valethamate Bromide.

7. If any other spasmolytic agent had been used within 48 hours.

After obtaining the homogenous group based on inclusion criteria, cases were randomly assign by computer generated number to Group I- Drotaverine and Group II to Valethamate Bromide. The medicine was injected in patients with established labor i.e. at 3 or $4 \mathrm{~cm}$ cervical dilatation with regular uterine contraction of $>2$ per 10 minutes and each lasting for 10 seconds.

In Group I $(n=100)$ cases received Intramuscular (IM) Drotaverine $40 \mathrm{mg}$ in supine position. Injection was repeated after 2 hours as per requirement (Cervical dilatation $<7 \mathrm{~cm}$ ) to maximum of three Injections.

In Group II $(n=100)$ cases received IM injection of Valethamate Bromide $8 \mathrm{mg}$ at hourly interval to maximum of three.

Continues monitoring of maternal and fetal condition was observed. Any abnormality if detected was managed accordingly. Evaluation of uterine activity was observed $1 / 2$ hourly to assess the frequency and duration of contraction.

Any relation with drug administration to uterine contraction was especially noted.

Per vaginum examination was performed at the beginning of labour, at the time of administration of Drotaverine or Valethamate Bromide hourly, during labor and at further doses of drug, if required. 
All events of labor were graphically recorded in the form of Partograph. If labor did not end within 12 hours spontaneously, it was considered as failure of acceleration of labor and other methods of termination of pregnancy were looked for. Other outcome variables like injection delivery interval, total doses of drug required, route of delivery, incidence of operative interference, duration of first, second and third stages of labor, amount of blood loss, complications of the third stage like cervical tear, retained placenta, post-partum hemorrhage etc. were noted. Foetal outcome in terms of live or stillbirth, weight, Apgar scoring at $1 \mathrm{~min}$ and $5 \mathrm{~min}$ were recorded. Both mother and the baby were followed up for at least 48 hours.

\section{RESULTS}

In the present study there was no significant difference in the demographic distribution, socioeconomic state, age, gravidity and registration of case in both the groups (Table 1).

Table 1: Demographic parameters.

\begin{tabular}{|c|c|c|}
\hline Parameters & $\begin{array}{l}\text { Drotaverine } \\
\text { Group-I }\end{array}$ & $\begin{array}{l}\text { Valathamate } \\
\text { Group-II }\end{array}$ \\
\hline No. of women & 100 & 100 \\
\hline \multicolumn{3}{|c|}{ Age group in years } \\
\hline $18-25$ & 80 & 72 \\
\hline $26-35$ & 20 & 28 \\
\hline Urban & 100 & 100 \\
\hline Rural & 0 & 0 \\
\hline \multicolumn{3}{|c|}{ Socio Eco Status } \\
\hline Low & 70 & 74 \\
\hline Middle & 30 & 26 \\
\hline \multicolumn{3}{|l|}{ Gravidity } \\
\hline Primigravida & 56 & 54 \\
\hline Multigravida & 44 & 46 \\
\hline \multicolumn{3}{|l|}{ Registered } \\
\hline Booked & 78 & 70 \\
\hline Unbooked & 22 & 30 \\
\hline
\end{tabular}

It has been observed that average duration of first stage of labor was shortening significantly in Drotaverine group (149.78 minutes) than Valethamate Bromide group (294.62 minutes).

Duration of active first stage of labor was also shorten in primigravida in Group-I, It was 170.22 minute compare to Group-II which was 321.71 minute. Mean duration of first stage of labor was shorten significantly in Group-I in multigravida which was 129.35 minutes. In Group-II it was 267.54 minutes. There is no significant difference in duration of second and third stage of labor in both the groups (Table 2).
Table 2: Duration of various stages of labor in minutes.

\begin{tabular}{|lll|}
\hline Stages & Group-I & Group-II \\
\hline $\begin{array}{l}\text { Mean duration of active first } \\
\text { stage of labor }\end{array}$ & 149.78 & 294.62 \\
\hline $\begin{array}{l}\text { Mean duration of active } \\
\text { phase in Primi }\end{array}$ & 170.22 & 321.71 \\
\hline $\begin{array}{l}\text { Mean duration of active } \\
\text { phase in Multies }\end{array}$ & 129.35 & 267.54 \\
\hline $\begin{array}{l}\text { Mean duration of second } \\
\text { stage of labor }\end{array}$ & 22.05 & 22.49 \\
\hline $\begin{array}{l}\text { Mean duration of Third stage } \\
\text { of labor }\end{array}$ & 8.62 & 8.92 \\
\hline
\end{tabular}

Injection to delivery interval was shorten in Drotaverine group both in Primi and Multi gravid. Group-I in Primi 197.22 minutes and 156.35 in Multies while in Group-II in Primi 346.71 minutes and in Multies 292.54 minutes (Table 3).

Table 3: Injection to delivery interval in minutes.

\begin{tabular}{|l|ll|}
\hline Gravida & Group-I & Group-II \\
\hline Average & 176.78 & 319.62 \\
\hline Primigravida & 197.22 & 346.71 \\
\hline Multigravida & 156.35 & 292.54 \\
\hline
\end{tabular}

Average number of injection used in Group-I was 1.7 while in Group-II 2.99. It was significantly smaller number of injection used in Drotaverine group (Table 4).

Table 4: No of injections used.

\begin{tabular}{|lll|}
\hline No. of Injection Used & Group-I & Group-II \\
\hline Average No of Injection Used & 1.7 & 2.99 \\
\hline
\end{tabular}

Average rate of cervical dilatation in Group-I was 2.81 $\mathrm{cm} /$ hour. In Primigravida it was $2.50 \mathrm{~cm} /$ hour while in Multi gravid it was $3.33 \mathrm{~cm} /$ hour.

In Group-II average rate was $1.42 \mathrm{~cm} / \mathrm{hour}$, in primigravida it was $1.30 \mathrm{~cm} /$ hour and in Multigravida $1.57 \mathrm{~cm} /$ hour (Table 5).

Table 5: Average rate of cervical dilatation $\mathrm{cm} / \mathrm{hour}$.

\begin{tabular}{|lll|}
\hline Rate of Cervical dilation & Group-I & Group-II \\
\hline $\begin{array}{l}\text { Average rate of cervical dilation } \\
\text { cm/hour }\end{array}$ & 2.81 & 1.42 \\
\hline $\begin{array}{l}\text { Average rate of cervical dilation } \\
\text { cm/hour in Primi }\end{array}$ & 2.50 & 1.30 \\
\hline $\begin{array}{l}\text { Average rate of cervical dilation } \\
\text { cm/hour in Multies }\end{array}$ & 3.33 & 1.57 \\
\hline
\end{tabular}


Table 6: Side effects.

\begin{tabular}{|lllll|}
\hline Side Effects & \multicolumn{2}{c}{ Group-I } & \multicolumn{2}{c|}{ Group-II } \\
& No & $\%$ & No & $\%$ \\
\hline Tachycardia & 4 & 4 & 31 & 31 \\
\hline $\begin{array}{l}\text { Dryness of } \\
\text { Mouth }\end{array}$ & 0 & 0 & 19 & 19 \\
\hline Flushing of face & 0 & 0 & 8 & 8 \\
\hline Nausea Vomiting & 1 & 1 & 2 & 2 \\
\hline Hypotension & 0 & 0 & 0 & 0 \\
\hline Fever & 0 & 0 & 0 & 0 \\
\hline Rash & 0 & 0 & 0 & 0 \\
\hline
\end{tabular}

Side effects like tachycardia were $4 \%$ in Group-I and $31 \%$ in Group-II. Dryness of mouth, flushing of face was more observed in Group-II (Table 6).

There is no significant difference of mode of delivery. No newborn in Group-I has Apgar score less than 8 at birth but in Group-II four newborn had Apgar score less than 8 at birth.

There was no foetal death in the groups, one case of PPH and one case of cervical tear found in Group-II (Table 7).

Table 7: Mode of delivery, neonatal outcome and complication.

\begin{tabular}{|lll|}
\hline Mode of delivery & Group I & Group II \\
\hline Vaginal & 97 & 95 \\
\hline LSCS & 3 & 5 \\
\hline Apgar Score & $8-10$ & $\begin{array}{l}<8 \text { in } 4 \\
\text { cases }\end{array}$ \\
\hline Complications & Nil & $\begin{array}{l}\text { PPH-01 } \\
\text { Cervical } \\
\text { Tear-01 }\end{array}$ \\
\hline
\end{tabular}

\section{DISCUSSION}

Acceleration of labor is considered to be an important factor in reducing maternal and neonatal morbidity. ${ }^{1}$ Since long back Valethamate Bromide is used to relive cervical spasm. ${ }^{6}$

A newer drug Drotaverine is an iso-quinoline derivative acting by inhibition of phosphodiesterase enzyme type four4.That causes relaxation of smooth muscles. In addition it also has spasmolytic action. ${ }^{5}$

In our study Drotaverine is used during active dilatory phase of labor and results were compared with IM Valethamate Bromide injection. It was found Intramuscular administration of Drotaverine significantly reduces the duration of cervical dilatation and total delivery time. Drug is safe and does not alters delivery parameters, with no adverse effect on mother and fetus. ${ }^{1-4}$
In present study duration of delivery is significantly shorten in Drotaverine group which is similar to finding of Kaur1 $149.82 \pm 63$ minutes.

Mishra SL et al (2002) studied effect of Drotaverine and Valethamate Bromide on cervical dilatation. They found average rate of cervical dilatation in primigravida with Drotaverine was $2.05 \mathrm{~cm} /$ hour and with Valethamate Bromide $1.53 \mathrm{~cm} /$ hour. In Multigravida it was 3.68 $\mathrm{cm} /$ hour and $2 \mathrm{~cm} /$ hour respectively. They found with Drotaverine the duration of labor was significantly shorten. ${ }^{2}$ In our study we have observed almost similar findings.

Pai et al. (2003) also found similar effect on cervical dilatation, shortening of labor time in their study. ${ }^{3}$

Ranka, Khosla also found Drotaverine is very effective agent to relive cervical spasm. ${ }^{7,8}$

Malay et al., Sharma JB, Nagria found Valethamate Bromide had more anti cholinergic side effects than Drotaverine. The same finding we have observed in our study.

Drotaverine improves the cervical dilation rate which is supported by various previous studies (Table 8).

In present study cervical dilatation rate was significantly higher and faster in Drotaverine group in comparison to Valethamate Bromide group. The results were similar to observations found in study conducted by Nagaria et al. ${ }^{11}$

Drotaverine is associated with higher rate of cervical dilatation, shorten the first stage of labor with few adverse effect in therapeutic dose as compared to Valethamate Bromide. ${ }^{8-11}$ In present study we also observed the Drotaverine group had identical results.

Valethamide Bromide is associated with higher incidence of adverse effect in therapeutic dose. ${ }^{1,6,8,11}$ Moreover present study also shows significantly higher incidence of minor adverse effect with Valethamate Bromide. Duration of second stage, third stage of labor, mode of delivery, maternal and neonatal outcome were similar in both group. ${ }^{12}$

\section{CONCLUSIONS}

Drotaverine significantly shortens the duration of first stage of labour and does not interfere with uterine contractility. Moreover it found to be safe with no adverse effect on mother and foetus. For this reason it is a better choice than Valethamate Bromide for shortening at the first stage of labour if used after proper selection of cases.

Funding: No funding sources Conflict of interest: None declared

Ethical approval: Approved by institutional ethics committee 
Table 8: Comparative evaluation of previous studies.

\begin{tabular}{|c|c|c|c|c|c|c|c|c|c|c|c|}
\hline No & Authors & $\begin{array}{l}\text { Drotaverine } \\
\text { Dose }\end{array}$ & $\begin{array}{l}\text { Rate of } \\
\text { Cervical } \\
\text { Dilatation } \\
\mathrm{cm} / \mathrm{min}\end{array}$ & $\begin{array}{l}\text { Duration } \\
\text { of first } \\
\text { stage } \\
\text { (Minute) }\end{array}$ & $\begin{array}{l}\text { IDI in } \\
\text { Minutes }\end{array}$ & $\begin{array}{l}\text { Side } \\
\text { Effects }\end{array}$ & $\begin{array}{l}\text { Valethamate } \\
\text { Bromide } \\
\text { Doses }\end{array}$ & $\begin{array}{l}\text { Rate of } \\
\text { Cervical } \\
\text { Dilatation } \\
\mathrm{cm} / \mathrm{min}\end{array}$ & $\begin{array}{l}\text { Duration of } \\
\text { first stage } \\
\text { (Minutes) }\end{array}$ & $\begin{array}{l}\text { IDI }^{*} \text { in } \\
\text { Minutes }\end{array}$ & $\begin{array}{l}\text { Side } \\
\text { Effects }\end{array}$ \\
\hline 1 & $\begin{array}{l}\text { Malay } \\
(2000)^{10}\end{array}$ & $\begin{array}{l}\text { 40mg I.V } \\
\text { Infusion }\end{array}$ & 2.71 & $\begin{array}{l}P^{*}-174.7 \\
M^{*} 148.72\end{array}$ & - & $1 \%$ & $\begin{array}{l}16 \mathrm{mg} \mathrm{IV} \\
\text { infusion }\end{array}$ & 2.39 & $\begin{array}{l}P^{*}-196 \pm 16 \\
M^{*}-176.96\end{array}$ & - & $\begin{array}{l}\text { DM }^{*} \\
28 \% \\
\text { P 04\% } \\
\text { M 03\% }\end{array}$ \\
\hline 2 & $\begin{array}{l}\text { Sharma } \\
(2001)^{6}\end{array}$ & $\begin{array}{l}40 \mathrm{mg} \text { IM } 2 \\
\text { hourly } \\
\text { maximum } 3 \\
\text { inj }\end{array}$ & 2.04 & & 194 & $\begin{array}{l}\mathrm{N}-4 \% \\
\mathrm{~T}-4 \%\end{array}$ & $\begin{array}{l}8 \mathrm{mg} \text { IM } \\
\text { 1hourly for } 3 \\
\text { doses }\end{array}$ & 1.87 & & 220.7 & $\begin{array}{l}\mathrm{DM}^{*} 10 \% \\
\text { P } 20 \% \\
\text { M } 41 \%\end{array}$ \\
\hline 3 & $\begin{array}{l}\text { Mishra } \\
(2002)^{2}\end{array}$ & $40 \mathrm{mg} \mathrm{IM}$ & $\begin{array}{l}\mathrm{P}^{*}-2.05 \\
\mathrm{M}^{*}-3.68\end{array}$ & $\begin{array}{l}\mathrm{P}^{*}-205 \\
\mathrm{M}^{*}-105\end{array}$ & & $2 \%$ & $\begin{array}{l}8 \mathrm{mg} \text { IM } \\
1 / 2 \text { hourly } \\
\text { maximum } 6 \\
\text { inj }\end{array}$ & $\begin{array}{l}\mathrm{P}^{*}-1.53 \\
\mathrm{M}^{*}-2.00\end{array}$ & & - & \\
\hline 4 & $\begin{array}{l}\text { Ranka } \\
(2002)^{7}\end{array}$ & 40mg IM & & 190 & & $\begin{array}{l}\mathrm{N}-2 \% \\
\mathrm{~T}-2 \%\end{array}$ & & & & - & \\
\hline 5 & $\begin{array}{l}\text { Kaur } \\
(2003)^{1}\end{array}$ & 40mg IM & $3.99 \pm 2.21$ & 116.34 & 149.82 & $\begin{array}{l}\mathrm{H}- \\
3.2 \% \\
\mathrm{~T}-4 \%\end{array}$ & $\begin{array}{l}8 \mathrm{mg} \text { IM } \\
\text { 1hourly for } 3 \\
\text { doses }\end{array}$ & 2.74 & 158.78 & 191.32 & $\begin{array}{l}\text { H-2\% } \\
\text { DM- } \\
10 \% \\
\text { T-28\% } \\
\text { F-6\% }\end{array}$ \\
\hline 6 & $\begin{array}{l}\text { Pai } \\
(2003)^{3}\end{array}$ & $40 \mathrm{mg} \mathrm{IM}$ & & $\begin{array}{l}P^{*}-194.3 \\
M^{*}-165.8\end{array}$ & & None & & & & & \\
\hline 7 & $\begin{array}{l}\text { Khosla } \\
(2003)^{8}\end{array}$ & $40 \mathrm{mg} \mathrm{IM}$ & & 175.92 & & None & $\begin{array}{l}8 \mathrm{mg} \text { IM } \\
1 / 2 \text { hourly for } \\
3 \text { doses }\end{array}$ & & & & $\begin{array}{l}\text { Minimu } \\
\mathrm{m} \mathrm{SE}\end{array}$ \\
\hline 8 & $\begin{array}{l}\text { Singh } \\
(2004)^{9}\end{array}$ & $\begin{array}{l}\text { 40mg IM } 4 \\
\text { hourly } \\
\text { maximum } 3 \\
\text { inj }\end{array}$ & 2.35 & 265.44 & & & & & & & \\
\hline 9 & $\begin{array}{l}\text { Nagaria } \\
(2009)^{11}\end{array}$ & $\begin{array}{l}\text { 40mg IM } 2 \\
\text { hourly } \\
\text { maximum } 2 \\
\text { inj }\end{array}$ & $\begin{array}{l}\text { Total-3.38 } \\
\mathrm{P}^{*}-2.89 \\
\mathrm{M}^{*}-4.55\end{array}$ & 113.51 & 135.87 & $\begin{array}{l}\mathrm{N}-3 \% \\
\mathrm{~V}-1 \% \\
\mathrm{~T}-3 \%\end{array}$ & $\begin{array}{l}16 \mathrm{mg} \text { IV } \\
\text { infusion }\end{array}$ & & & & $\begin{array}{l}\text { N-5\% } \\
\text { V-2\% } \\
\text { T-9\% } \\
\text { DM- } \\
22 \% \\
\text { F-2\% }\end{array}$ \\
\hline 10 & $\begin{array}{l}\text { Jayashree } \\
\text { S et.al } \\
(2013)^{12}\end{array}$ & $\begin{array}{l}40 \mathrm{mg} \text { IM } 2 \\
\text { hourly } \\
\text { maximum } 2 \\
\text { inj }\end{array}$ & $\begin{array}{l}\text { P-3.31 } \\
M-3.71\end{array}$ & $\begin{array}{l}\text { P-123.12 } \\
\text { M- } \\
113.94\end{array}$ & & & $\begin{array}{l}8 \mathrm{mg} \text { IM } \\
1 / 2 \text { hourly } \\
\text { maximum } 3 \\
\text { inj }\end{array}$ & $\begin{array}{l}\text { P-2.58 } \\
M-2.61\end{array}$ & $\begin{array}{l}\text { P-180.40 } \\
\text { M-147.12 }\end{array}$ & & \\
\hline 11 & $\begin{array}{l}\text { Present } \\
\text { Study } \\
(2013- \\
14)\end{array}$ & $\begin{array}{l}40 \mathrm{mg} \text { IM } 2 \\
\text { hourly } \\
\text { maximum } 3 \\
\text { inj }\end{array}$ & $\begin{array}{l}\text { Avg-2.81 } \\
\mathrm{P}^{*}-2.50 \\
\mathrm{M}^{*}-3.33\end{array}$ & 149.78 & $\begin{array}{l}\text { Avg } \\
176.78 \\
\text { P-197.22 } \\
\text { M 156.35 }\end{array}$ & $\begin{array}{l}\mathrm{T}-4 \% \\
\mathrm{~N}-1 \%\end{array}$ & $\begin{array}{l}8 \mathrm{mg} \text { IM } \\
\text { 1hourly for } 3 \\
\text { doses }\end{array}$ & $\begin{array}{l}\text { Avg-1.42 } \\
\text { P-1.30 } \\
\text { M-1.57 }\end{array}$ & $\begin{array}{l}\text { Avg 294.62 } \\
\text { P-321.71 } \\
\text { M-267.54 }\end{array}$ & $\begin{array}{l}\text { Avg } 319.62 \\
\text { P-346.71 } \\
\text { M-292.54 }\end{array}$ & $\begin{array}{l}\mathrm{T}-31 \% \\
\mathrm{D}-19 \% \\
\mathrm{~F}-08 \%\end{array}$ \\
\hline
\end{tabular}

Abbreviations: P-Primigravida, M-Multigravida, IDI-Injection Delivery interval, DM-Dryness of Mouth, T-Tachycardia, N-Nausea, V-Vomiting, F-Flushing, P-Palpitation

\section{REFERENCES}

1. Kaur D, Kaur R. Comparision of Drotaverine and Epidosin in first stage of labor. J obstet gynecol Ind. 2003;53:449-53.

2. Mishra S, Anju T, Runoo B. Effect of drotaverine on cervical dilatation- A comparative study with epidosin. J obstel gynecol Ind. 2002;52:76-9.

3. Pai V, Gupta K, Chaterjee N. Effect of Drotaverine on the active phase of labour-A controlled clinical trial. Obs \& Gynae Today. 2003;8:3.
4. Blasko G. pharmacology, mechanism of action and clinical significant of a convenient antispasmodic agent: Drtaverine. JAMA India. 2001;4:55-6.

5. Romic I, Molnar D, Timberg G, Blasko G. The effect of Drotaverine Hydrochloride in active colicky pain caused by renal and ureteric stones. BJU international. 2003;92:92-6.

6. Sharma J, Pundir P, Kumar A, Murty N. Drotaverine Hydrochloride Vs. Valethamide Bromide in acceleration of labor. International Journal of Gynaecology \& Obstetrics India. 2001;74:255-60.

7. Poornima R, Ranka A, Hishikar. Effect of drotaverine Hydrochloride on normal labor-A 
Randomized study. J of obit \& Gyn of Ind. 2002;52:28-30.

8. Anju H, Khosla I, Dahiya K. A comparative study of Valethamide Bromide with Drotaverine in normal labor. I obstet gynecol Ind. 2003;53:568-70.

9. Singh KC, Jain P, Goel N, Saxena A. Drotaverine Hydrochloride for augmentation of labor. Internal Journal of Gynaecology and Obstetrics. 2004;84:1722.

10. Malay S, Bejoylakshmi G, Biswas B. A study of Drotaverine on duration of first stage of Labor.JIMSA. 2000;13(4):256-7.
11. Nagaria T, Jaisawal J. To compare and evaluate the efficacy and safety of Drotaverine and Valethamide Bromide. I obslet gynecol India. 2009;59:324-31.

12. Jayashree S, Virupaksha A, Sujatha M. Comparison of drotaverine and valethamate bromide in first stage of labor. Int J Biol Med Res. 2013;4(2):3215-8.

Cite this article as: Jogi SR. To compare the efficacy of Drotaverine Hydrochloride and Valethamate Bromide in shortening of the first stage of labour. Int J Reprod Contracept Obstet Gynecol 2015;4:1038-43. 